\author{
ДИМИТРИНА СПАСОВА ЛЕСНЕВСКАЯ* \\ Университет национального и мирового хозяйства \\ София, Болгария

\section{ТРАДИЦИИ И СОВРЕМЕННОЕ СОСТОЯНИЕ ИССЛЕДОВАНИЙ ДЕЛОВОГО РУССКОГО ЯЗЫКА В БОЛГАРСКОЙ РУСИСТИКЕ}

\begin{abstract}
В статье прослеживается развитие теории и методологии исследования делового русского языка в трудах болгарских русистов в хронологическом порядке. Анализу подвергаются функционально-стилевой, дискурсивно-стилистический, дискурсивный, прагмалингвистический и когнитивно-прагматический аспекты изучения делового русского языка, причем устанавливается, что в большей части работ используется сопоставительный метод исследования двух родственных славянских бизнес-языков - русского и болгарского. Обращается внимание на важную роль международных конференций и симпозиумов, научных журналов и сборников, контактов с русистами из разных стран в формировании и развитии теории бизнес-языка в болгарской русистике.
\end{abstract}

Ключевые слова: парадигма, деловой язык, официально-деловой стиль, деловой дискурс, межкультурный деловой дискурс, эпистолярный дискурс, деловые письма, коммерческие письма, когнитивно-прагматический подход

В настоящее время исследования в области делового русского языка в болгарской русистике базируются на новой межкультурной парадигме ${ }^{1}$. Новому лингвистическому направлению межкультурной коммуникации (общения между представителями различных культур) и соответственно методическому направлению межкультурной лингводидактики (иноязычного обучения как диалога равноправных культур - родной и инородной) были посвящены доклады юбилейной международной конференции Общества русистов Болгарии, София, 29 июня - 2

*demetra3@gmail.com

${ }^{1}$ Мишланова С.Л., Пермякова Т.М. Межкультурная парадигма и перспективы межкультурной коммуникации. Стереотипность и творчество в тексте. Межвуз. сб. науч. тр., № 8. 2005. - С. $340-350$. 
июля 2017 г. ${ }^{2}$, а также статьи в журналах «Болгарская русистика» и «Русистика без граници» ${ }^{3}$.

Рассмотрим в хронологическом порядке исследования делового русского языка в трудах болгарских русистов, прослеживая научные лингвистические парадигмы, в русле которых они проводились. Под научной лингвистической парадигмой понимаем подход, модель или метод исследования, широко признанный и утвержденный в лингвистическом мире ${ }^{4}$.

\section{1. Становление функциональной парадигмы. Официально-деловой функциональный стиль $(1980-1999$ гг.)}

В Болгарии во второй половине XX века научные исследования и учебная литература в области официально-делового функционального стиля базировались на теоретических постулатах Пермской школы

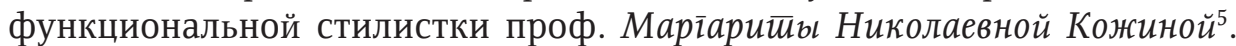
В связи с преподаванием русского профессионального делового языка в экономических и др. незыковых вузах создавалось множество учебников и учебных пособий по русскому языку в сфере экономики, туризма и др. с разделами, посвященными устному и письменному деловому языку, в частности, профессиональному диалогу и коммерческой корреспонденции (Анастиасия Дрехарова, Наgежgа Полякова, Ольїа Байgак, Римма Георитева, Анасииасия Цонева, Лариса Кожухарова, Евсевия Москова, Пен-

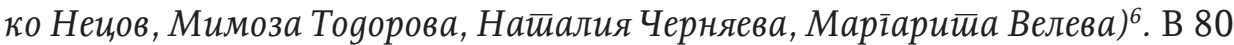
-90-ые гг. прошлого века были разработаны различные теоретические

2 Лесневска Д.С. Диалог культур на занятиях по деловому русскому языку в болгарской аудитории.

${ }^{3}$ Тарева Е. Культура как ключевой концепт лингводидактики// Русистика без граници. - 2017.- № 1. - С. 88-98; См. также Тарева Е. Межкультурный подход как инновационная лингводидактическая стратегия // Болгарская русистика . - 2015. - № 3-4. - С. $165-175$.

${ }^{4}$ Хомутова Т.Н. Научные парадигмы в лингвистике // Вестник Челябинского гос. У-тета. № 35 (173). Филология. Искусствоведение. Вып. 37., 2009. С. 142-151.

${ }^{5}$ Кожина М.Н. Стилистика русского языка. М.: Просвещение. 1983. - 217 с.

${ }^{6}$ Полякова Н., Дрехарова А., Байдак О., Георгиева Р. Внешнеторговая корреспонденция и документация. Учебник для студентов III и IV курсов факультета международных экономических отношений ВИИ им. Карла Маркса. София: Наука и изкуство. - 298 с.; Цонева А., Кожухарова Л., Тодорова М., Черняева А., Нецов П. Русский язык: Корректировочный курс, Деловое общение, Коммерческая корреспонденция для студентов Экономического у-тета. Варна: Эк. У-тет. 1994. - 360 с.; Цонева А. Русский язык для деловых контактов в туризме. Деловая документация и корреспонденция в туризме. Этика и этикет в деловом общении. Телефонный разговор. Варна: Эк. У-тет. 1996.- 240 
аспекты русского делового языка (Т. Чалакова, Й.Сиеефанова, С. Ноева, Л. Павлова, А. Енева, С. Георіиева, Е. Солниева-Накова) ${ }^{7}$. Были проанализированы лингвострановедческий, этно- и социологический аспекты современной деловой культуры (А. Цонева), русское коммунитакивное поведение и особенности русского интерьера (Н. Черняева); был рассмотрен подъязык переговоров на русском языке в сопоставлении с родным болгарским, а также определен лингвокультурологический тезаурус бизнес-языка (А. Цонева); проанализированы в теоретическом и методическом планах туристская документация (А. Цонева, М. Тоgорова) и фразеологизированные формулы в деловой корреспонденции в болгарском, русском и сербохорватском языках (В. Найgенова). Исследованию подвергались также модели синтаксической сочетаемости в языке туристской документации ${ }^{8}$.

В русле методики преподавания русского языка как иностранного (РКИ) были исследованы профессионально-деловые игры (E. Ка-

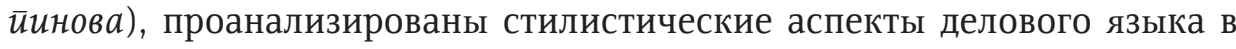
сфере туристского обслуживания (Г. Драі̄оева-Тальская), разработаны основные направления бизнес-курса русского языка (С. Георіиева). На VI Международном симпозиуме МАПРЯЛ, проведенном в г. ВеликоТырново, Болгария, 1995, Сиеефка Георіиева представила свой доклад на тему «О новых бизнес-терминах в русском и болгарском языках». В 1994 г. в Софийском университете им. Климента Охридского Елизаве-

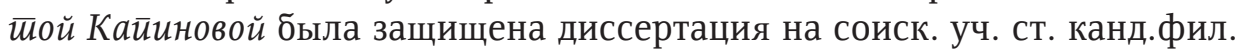
наук: «Профессионально-деловая игра в обучении профессиональному общению на русском языке студентов-нефилологов».

Из приведенного выше краткого обзора видно, что в конце прошлого века болгарские исследования в области делового русского языка охватывали широкий тематический спектр, включая терминологию, лексику, грамматику, стилистическое своеобразие, национальный и социологический колорит делового общения и деловой культуры в их письменном и устном вариантах, включая деловые письма, документацию, деловые и профессионально-деловые диалоги, полилоги и т.п.

с.; Цонева А. Русский язык для делового общения. Корректировочный курс. Страноведение. Язык бизнеса. Варна: Кръг. 1998. - 190 с.

7 Языковедческая русиситка в Болгарии. Библиографический указатель. 1983 - 2007. Шумен: Унив.изд.. 2007. - 328 с.

8 Цонева А. Модели синтаксической сочетаемости в языке туристской документации // Болгарская русистика, № 6. 1988. С. 61-71. 


\section{2. Функционально-стилистическая парадигма. \\ Бизнес-язык, язык для специальных целей, подъязык, функциональный стиль, жанр (2000-2007 гг.)}

В начале настоящего века были приняты общеевропейские уровни владения иностранными языками и разработаны вузовские учебные программы обучения русскому языку в соответствии с общеевропейскими компетенциями и на базе функционально-стилистического подхода к обучению РКИ в болгарской среде, причем во все уровни было включено владение деловым языком, в том числе умение составлять деловые письма. В Болгарии был утвержден коммуникативный метод обучения иностранным языкам, в частности обучения РКИ, базирующийся на принципах функциональности и коммуникативности 9 . В этот период закладываются основы болгарской профессиональной лингводидактики, вырабатываются новые стратегии и тактики в поисках более эффективных способов структурирования учебного процесса профессионально-ориентированного обучения РКИ, утверждается сопоставительное изучение русского и болгарского бизнес-языков, уточняются понятия «бизнес-язык», «язык для специальных целей», «подъязык делового общения», жанровые разновидности бизнес-текстов (Е. Кайинова, Д. Лесневская) ${ }^{10}$. К наиболее исследованным вопросам относятся невербальная коммуникация в сфере делового общения (E. Кайинова), унификация деловой переписки в туризме (В. Бонев), лингвостилистические особенности русских и болгарских коммерческих писем в сопоставительном плане, специфика устного и письменного делового общения, характеристика документации, классификация коммерческих писем (Д. Лесневска) и др. (Библиографический указатель 2007).

На основе теории функционального официально-делового языка созданы учебники и словари в области делового общения, бизнеса и коммерции ${ }^{11}$. На данный период времени профессиональная лингво-

${ }^{9}$ Лесневска Д. Функционалната стилистика и чуждоезиковото обучение в икономически ВУЗ //Юбилейна международна конференция, том 2. Свищов: СА «Д.А. Ценов». - 2001. - С. 351-356.

${ }^{10}$ Капинова Е. Деловите игри в обучението по професионално общуване. Университеет "Проф. Ас.Златаров". Колеж по туризъм. Бургас: 2000. - 110 с.; Лесневска Д. Търговска кореспонденция на руски и български език (съпоставителен лингвостилистичен анализ). София: УИ “Стопанство". - 2002. - 135 с.; Лесневска Д. Особенности современного русского и болгарского бизнес-языков // Мир русского слова и русское слово в мире. Том 3. ХІ конгресс МАПРЯЛ. София: Херон Прес. - 2007. -416-422.

${ }_{11}$ Боянова Н., Шопова В. Деловое общение на русском языке. София: Велес. - 203. - 135 с.; Владова И., Владова К. Български, руски и английски за делови контакти. София, 1996; Георгиева С. Руско-български и българо-руски бизнес речник. София: Хейзъл. 2004. -488 с. 
дидактика в области обучения деловому русскому языку в болгарской среде активно разрабатывается (Д. Лесневска, А. Пенчева) ${ }^{12}$.

\section{3. Коммуникативно-прагматическая и когнитивно-дискурсивная} парадигмы как направления антропоцентрической парадигмы.

Неофункциональная интегральная парадигма.

Официально-деловой дискурс. Межкультурный

деловой дискурс. Межкультурная парадигма (2008-2017 гг.)

Идея антропоцентричности, базирующаяся на взаимосвязи культуры и языка, является ключевой для современной лингвистики. Антропоцентрическая парадигма является ведущей лингвистической парадигмой, в которую включаются неофункциональная, лингвокультурологическая и лингвосоциологическая парадигмы. Неофункциональная парадигма объединяет когнитивную (в частности, когнитивная лингвистика, лингвоконцептология, психолингвистика и др.) и коммуникативную (в частности, коммуникативная лингвистика, прагмалингвистика, дискурсология, корпусная лингвистика и др.) парадигмы. Итак, неофункциональная интегральная парадигма включает в себя коммуникативно-прагматическую и когнитивно-дискурсивную парадигмы. Рассмотрим сначала исследования делового русского языка в Болгарии в контексте коммуникативно-прагматической парадигмы.

Коммуникативно-прагматическая парадигма как одно из направлений антропоцентрической парадигмы имеет междисциплинарный характер, интегрируя основные подходы и базисные категории коммуникативной и прагматической лингвистики. Основными объектами данной парадигмы являются субъект речи, адресат, взаимоотношения между коммуникантами, ситуации общения, речевые акты, дискурс. Новой теоретической базой профессиональной лингводидактики становятся достижения коммуникативной стилистики - типология дискурса в профессиональной коммуникации, комплексный подход к тексту, коммуникативно-деятельностный подход к языку ${ }^{13}$. Официально-деловой дискурс представляет собой коммуникативно-когнитивное событие

12 Лесневска Д. Преподавание русского языка как иностранного в специальных целях - состояние, проблемы, перспективы // Болгарская русистика, № 1-2, 2003. - С. 45-49; Лесневска Д. Деловая корреспонденция в учебно-методическом плане // Болгарская русистика, № 3-4, 2005. - 60-67; Пенчева А. Актуальное в обучении русскому языку в сфере бизнеса и экономики // Икономиката и развитието на обществото. Международна Юбилейна научна конференция. T.V. Варна: Икон.у-тет. - 2002. - C. 148-150.

${ }^{13}$ Лесневска Д. Коммуникативная стилистика и преподавание русского языка как иностранного в неязыковых вузах // МАПРЯЛ 2014. Одиннадацатый международный симпозиум. Доклады и сообщения. Велико-Тырново: ИВИС. - 2014. - С. 569-572. 
социокультурного харакетра, процесс производства и понимания речи в коммуникативно-прагматической деловой среде, основными признаками которого являются институциональность, стабильность, стандартизованность, точность, соблюдение норм вежливости и речевого этикета ${ }^{14}$.

Современное иноязычное обучение реализуется в рамках инновационного межкультурного подхода через равноправный диалог культур по правилам межкультурного общения в контексте межкультурной парадигмы. Межкультурная коммуникация - это межличностная коммуникация при взаимодействии коммуникантов - представителей различных культурно-языковых групп. Межкультурный деловой дискурс представлен во множестве жанров: устных (деловая беседа, переговоры, презентация, деловое интервью) и письменных ( деловые письма, соглашение, контракт, договор, протокол $)^{15}$.

В рассматриваемый период публикуются монографии и статьи $E$. Кайиновой, посвященные невербальному деловому общению (Библиографический указатель 2013), методические статьи В. Бонева и А. Пенчевой, посвященные проблемам обучения русскому деловому языку в болгарской аудитории ${ }^{16}$.

Акцент ставится на исследования коммерческих писем: прослежена история развития болгарской деловой корреспонденции, коммерческая корреспонденция проанализирована в дискурсивно-стилиситческом аспекте ${ }^{17}$. Создаются новые учебники по деловому русскому языку:

14 Лесневска Д. Коммерческая корреспонденция: язык для специальных целей, эпистолярный дискурс, дискурс торговой сделки // Стереотипность и творчество в тексте, № 17. Пермь: Перм.гос. ун-т. 2013. - С. 75-84.

${ }^{15}$ Лесневска Д.С. Обучение межкультурному деловому дискурсу в теории и практике преподавания РКИ в болгарских неязыковых вузах // Стереотипность и творчество в тексте, № 18. - Пермь: Перм.гос.у-тет. 2014. - С. 293-301.

${ }^{16}$ Бонев В. Некоторые аспекты преподавания русского как бизнес-языка в болгарской аудитории // Международный симпзиум "Изученвие славянских языков, литератур и культур как инославянских и иностранных". Белград, 2008. - С. 42-47; Бонев В. К проблеме обучения русскому деловому языку в болгарской аудитории // МАПРЯЛ 10. Доклады и сообщения. Велико-Тырново, 2010. С. 618-621; Бонев В. К проблеме функционирования и преподавания русского как бизнес-языка // Чуждоезиковото обучение в системата на висшето професионално образование. ДЕО, Ун-т "Проф. д-р А. Златаров. Бургас. - С. 7-11; Пенчева А. Обучение деловой коммуникативной компетенции в неязыковом вузе // Современные технологии преподавания естественно-научных и гуманитарных дисциплин. Международный круглый стол. София, 2008. - С. 69-71; Пенчева А. Формирование бизнес-коммуникативной компетенции у студентов-экономистов в сфере межкультурной коммуникации // IV Международная научная конференция "Русский язык в языковом и культурном пространстве Европы и мира". Варшава, 2008. $-514-518$.

17 Лесневска Д. Болгарская деловая корреспонденция - от письмовника до электронного письма // Стереотипность и творчество в тексте, № 18. - Пермь: Перм.гос. 
Черняева Н., Тоgорова М. «Русский язык. Экономика и бизнес». Варна, 2008. Сочетание сопоставительного этносоциокультурного и дискурсивно-стилистического подходов при обучении профессиональному РКИ, в частности межкультурному деловому дискурсу в инославянской среде является предпосылкой творческого развитие болгарской методики преподавания русского языка как инославянского, в частности преподавания русского делового дискурса в болгарской среде. Проект „Изучение русского языка и русской культуры в инославянском окружении" был выдвинут проф. Боїолюбом Сйанковичем (Станкович 2010). Теоретическим и методологическим вопросам в области межкультурной коммуникации и межкультурного делового дискурса посвящен ряд статей Д. Лесневской : «Обучение межкультурному деловому дискурсу в теории и практике преподавания РКИ в болгарских нефилологических вузах» // Сб. Русский язык как инославянский, вып.VI /2014/. - Славистичко друштво Србије, Београд 2014 /191/. с. 102-110; «Дискурс торговой сделки в обучении русскому языку в инославянской среде» // Сб. Русский язык как инославянский, вып. VI /2014/. - Славистичко друштво Србије, Београд 2014 /191/. с. 148-156.

В своем пленарном докладе на Международном симпозиуме МАПРЯЛ 2010, г. Велико-Тырново, проф. Сиеефана Димийрова особо акцентировала роль лингвистической прагматики ${ }^{18}$ (теория речевых актов) как лингвистической основы коммуникативной методики обучения РКИ. Коммуникативно-прагматические ситуации выделяютя на базе косвенных речевых актов (Димитрова 2010). На следующем Международном симпозиуме МАПРЯЛ 2014, г. Велико-Тырново, проф. Сиеефана

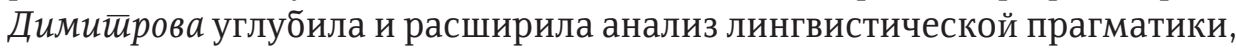
являющейся лингвистическим обоснованием теорий коммуникативной компетенции, дискурсивной ситуации, моделей дискурса (Димитрова 2014).

Упомянутая в вышеуказанных пленарных докладах проф. Сиеефаной Димитировой роль лингвистической прагматики, как исходной теоретической базы для новой межкультурной лингводидактики, реализована в разработке методики обучения русскому деловому дискурсу в болгарской аудитории в теоретическом и практическом планах ${ }^{19}$. На основе

У-тет. 2010. - С. 232-243; Лесневска Д. Коммерческая корреспонденция в дискурсивностилистическом аспекте // Русистика XXI века: традиции и перспективы. Шумен: УИ "Еп. Константин Преславски. 2013. - 131-138.

${ }^{18}$ Димитрова С. Лингвистична прагматика. - София: Велес. - 2009.

19 Лесневска Д. Прагмалингвистические особенности эпистолярного дискурса в обучении РКИ в болгарской аудитории // Русский язык и культура в зеркале перевода. VI Международная научная конференция 13-16 мая 2016 г. Греция, Афины. М.: МАКС Прогресс, 2016. - 674 с. - С. 27-284. 
теории прагмалингвистики (теория речевых актов, теория перформативности, перформативы: перформативные глаголы и перформативные высказывания) составлен учебный список перформативных клише, характерных для русского и болгарского эпистолярного дискурса с учетом их сравнительно-сопоставительных характеристик. Контрастивное исследование русского и болгарского эпистолярных дискурсов позволяет выявить глубже специфические особенности текстов деловых писем на двух родственных славянских языках.

По прагмалингвистической установке (типы речевых актов, в состав которых входят перформативные глаголы) разграничиваются следующие жанры деловых писем: извещение, напоминание, подтверждение, предложение, просьба, гарантия, запрос, ответ на запрос, заказ, отказ, предупреждение, приглашение, ответ на приглашение, благодарность, поздравление, извинение, сожаление. Коммуникативные функции эпистолярного дискурса обусловлены коммуникативно-прагматической осью «автор - адресат». По коммуникативным функциям (референтная, фатическая, импрессивная, экспрессивная) разграничиваются следующие виды деловых писем: уведомительные (письма, сообщающие информацию); креативные (письма, создающие деловые контакты); креативные (письма, воздействующие на адресата - перлокутивный эффект), эмотивные (письма, выражающие чувства и отношения коммуникантов к событиям и ситуациям).

Для эпистолярного дискурса русских и болгарских деловых писем характерными являются следующие типы речевых актов (по классификации Дж. Серля и Ю.Д. Апресяна): 1.Ассертивы; 2. Комиссивы; 3. Директивы; 4. Декларативы; 5. Экспрессивы.

Выделяются следующие модели речевого поведения русских и болгарских деловых писем в рамках прагмалингвистики: сообщение (набор ассертивов); обещание (набор комиссивов); просьба, предложение, рекламное письмо, приглашение, совет, предупреждение, напоминание, требование, запрет, разрешение (набор директивов); подтверждение, отказ, декларация, объявления (набор декларативов); благодарность, извинение, поздравление, прощание, пожелание, сожаление, надежда (набор экспрессивов). Разработан комплекс упражнений, направленный на осуществление диалога равноправных культур в рамках межкультурной коммуникации в учебном процессе (Лесневска Д.С. «Прагмалингвистические характеристики коммерческих писем на русском и болгарском языках в сопоставительном плане» // Русский язык как инославаянский. Вып. VIII. Белград, 2016. С. 39-46); «Соотношение рационального и эмоционального в эпистолярном дискурсе ( на материале русской и болгарской коммерческой переписки)» // Рациональное и эмоциональ- 
ное в русском языке. Сб. материалов международной научной конференции. М., 2016. - С. 216-220).

Обратим наше внимание на исследования делового русского языка в Болгарии в контексте когнитивно-дискурсивной парадигмы. При синтезе когнитивного и коммуникативно-прагматического подходов в рамках неофункциональной парадигмы выделяется когнитивно-прагматический подход, посредством которого исследуются когнитивнопрагматические особенности дискурса, рассматриваемого как концептуально-когнитивного теоретического конструкта.

Официально-деловой дискурс в рамках когнитивно-дискурсивной парадигмы рассматривается как единство коммуникативной ситуации, единиц языковой концептуализации (концептов), дискурсивных стратегий и тактик (интенций адресанта в деловом письме). Когнитивная и прагматическая парадигмы исследования делового дискурса взаимовлияют друг на друга и взаимодополняют друг друга. Анализ концептуальной структуры дискурса в когнитивно-прагматическом аспекте позволяет выявить составляющие его концепты (совокупности знаний и информаций), языковую репрезентацию и лингвопрагматические характеристики. Институциональный деловой дискурс - это целенаправленная речевая деятельность людей в рамках деловых отношений, коммуникация между организациями.

Эпистолярный дискурс, выделяемый в рамках делового дискурса, представляет собой особую монодиалогическую форму межличностной письменной коммуникации. Характерной особенностью дискурса является его экстралингвистические, национально-культурные характеристики. Так, дискурс - форма использования языка в реальном времени, речевое произведение, включающее текст и экстралингвистические факторы (участники коммуникации, коммуникативные цели, прагматические установки, социальные роли, социокультурный контекст, ситуации общения, фоновые знания), совокупность тематически общих текстов.

Следуя когнитивно-прагматическому подходу, деловые письма подразделяются на следующие типы в зависимости от коммуникативной цели, дискурсивной стратегии и набора концептов (обязательство/ отсутствие обязательства, необходимость/ отсутствие необходимости, польза, требование, известие, потребность, выгода/отсутствие выгоды, оценка, доверие, надежность, связи) в рамках новой когнитивно-прагматической парадигмы (Шеина 2012):

1. Информационные письма: уведомление, извещение, сообщение, напоминание (письма, побуждающие к действию); сопроводительное письмо (оповещение); рекламное письмо, отчет (убеждение). 
2. Письма, побуждающие адресата совершить действие: заявка, заказ, запрос, приглашение, просьба (побуждение); предложение (убеждение).

3. Письма, содержащие требование или претензию: требование, рекламация (требование).

4. Письма, сообщающие о принятом решении: отказ, согласие (сообщение).

5. Письма, содержащие обязательства, подтверждение, гарантии: гарантийное письмо, письмо-подтверждение (подтверждение); рекомендательное письмо (убеждение);

6. Этикетные письма: письмо - поздравление, соболезнование, благодарность, извинение, приглашение (выражение отношения).

Когнитивно-прагматической особенностью эпистолярного делового дискурса является его ядерная структура, где в ядре располагаются регламентированные письма с наибольшей стандартизованностью, а в периферии находятся нерегламентированные письма с большей вариативностью в тексте и языковом выражении (Шеина 2012). В ядре модели делового письма находятся такие жанры, как уведомление, извещение, заявка, запрос, заказ, требование, рекламация, отказ, согласие, гарантийное письмо. На среднем уровне расположены напоминание, сообщение, сопроводительное письмо, предложение, подтверждение, соболезноване, извинение, приглашение. На периферии находятся рекламное письмо, отчет, просьба, рекомендательное письчо, поздравление и благодарность.

Так, ядерный жанр «рекламация», имеющий набор концептов обязательства, требования, необходимости и потребности, а также четко выраженную императивность, содержит претензию (упрек), обоснование упрека и требование выполнить обязательство. Напр.: рус. Мы сильно обесйокоены иием фактиом, итио Ваша йостиавка уже оиоовала / болг. Ние

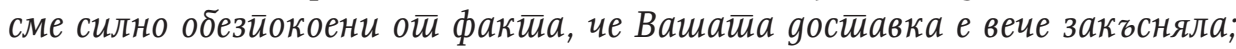

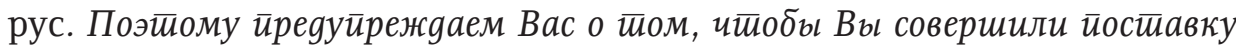

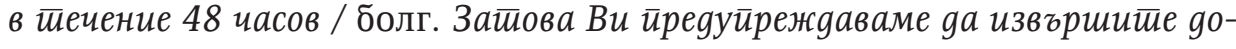
сииавкайа в иечение на 48 иаса.

Жанр «извинения» характеризуется большей вариативностью, находясь в средней полосе ядерной структуры эпистолярного делового

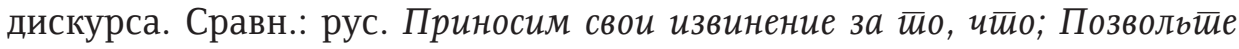
иринести свои извинения за; Искренне сожалеем за; Примите наши искренние извинения за; Еще раз ириносим свои извинения/ болг. Поянасяме

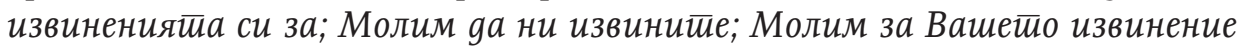

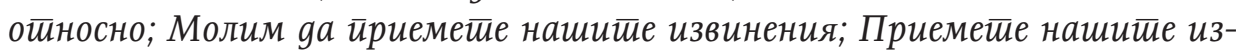
винения. 
Жанр «рекламное письмо», будучи синкретичным типом рекламного и делового текстов, допускает выраженную эмоциональность, находясь в области периферии ядерной структуры эпистолярного делового дискурса, напр.: рус./ болг.:

Выт̆онное ирредложение летинеі̄о сезона!

Предоставляем Вашему вниманию новейшие модели о gежgы, сумок и аксесуаров лейнетіо сезона. Новую лейнюю коллекиию найолняюй яркие ивейа. НОВИНКА СЕЗОНА - уникальная йлянная сумка.

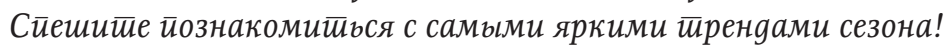
ДОБРО ПОЖАЛОВАТЬ В НАШ ТОРГОВЫЙ ЦЕНТР И ПРИЯТНЫХ ВАМ ПОКУПОК!

Приглашаем в салоны нашего центра на выгодное лето! /

Убедени сме, че ще остианете очаровани!

Новата ни колекция плажни чанти съчетава АКТУАЛНОСТ, ВИСОКО КАЧЕСТВО и РАЗУМНИ ЦЕНИ. Вашите клиенти ще оценят високо богатата гама от цветове, форми и материали на новия ни продукт!

Ще поЛучите СПЕЦИАЛНА НАЧАЛНА ОТСТЬПКА от 15 \% до 20 май 2013 г.

ОЧАКВАМЕ ВАШИТЕ ПОРЪЧКИ!

В современной русской и болгарской деловой переписке наблюдается тенденция развития большей степени субъективности и эмоциональности. Когнитивно-дискурсивный аспект теории эпистолярного делового дискурса является лингвистическим обоснованием межкультурного дискурсивного обучения иностранным языкам, в частности обучения РКИ в области деловой корреспонденции в Болгарии. Сопоставительное изучение русской и болгарской деловой переписки посредством применения когнитивно-прагматического подхода является исходной лингвистической основой преподавания русского языка как иностранного в области делового дискурса в болгарской аудитории ${ }^{20}$.

Итак, обзор исследований в области делового русского языка в Болгарии иллюстрирует поступательное развитие теории и практики делового общения в русле непрерывного процесса появления, развития и старения научных лингвистических парадигм в лингвистике. Так, в рассматриваемый период 1980-2017 гг. преподавание РКИ в области делового языка и лингвистическая теория, которая его обосновывает, развивались и менялись от коммуникативности к приниципам антро-

20 Лесневска Д. Когнитивно-прагматическая характеристика эпистолярного дискурса (на материале русских и болгарских деловых писем) // Юбилейная международная научная конференция „Рациональное и эмоциональное в русском языке”. МГОУ. Москва. 2017. (В печати). 
поцентричности, которые реализуют междисциплинарность - дискурсивность иноязычного обучения требует наличие страноведческого, культуророведческого, социокультурного, лингвокультуроведческого, психолингвистического концептов в учебных материалах. Характерной особенностью болгарских исследований русского бизнес-языка является их сопоставительный характер - сопоставление двух родственных языков (русского и инославянского) способствует более глубокому проникновению в специфику сравниваемых текстов. Сформулированы прагматическая и когнитивно-прагматическая классификации русских и болгарских деловых писем в сопоставительном плане. Установлены значимость роли международных конференций и симпозиумов (регулярно проводимый Международный симпозиум МАПРЯЛ в г. ВеликоТырново, Болгария), ценность контактов с коллегами-русистами всего мира (напр., проект «Русский язык как инославянский» выдающегося сербсккого слависта Боїолюба Сйанковича), потреб̆ость в периодических отечественных лингвистических журналах («Болгарская русистика», «Русистика без граници» и др.), на страницах которых излагаются актуальные проблемы и задачи научной и учебной деятельности болгарского лингвистического сообщества, в частности вопросы делового русского языка в теоретическом и дидактическом аспектах в болгарской среде, плодотворность сотрудничества с зарубежными лингвистическими журналами (сербские издания «Русский язык как инославянский», «Славистика»; Пермский периодический сборник «Стереотипность и творчество в тексте» и др.).

\section{ЛИТЕРАТУРА}

Библиографический указатель: 1983 - 2007. Языковедческая русистика в Болгарии.

Отв. ред. Аврамова В., Николова А. - Шумен: Ун.изд. «Епископ Константин Преславски», 2007. - 328 с.

Библиографический указатель: 2007-2013. Языковедческая русистика в Болгарии.

Отв. ред. Аврамова В. - Шумен: Ун.изд. «Епископ Константин Преславски», 2013. - 143 c.

Димитрова С. Рассуждения о месте прагматики в описании и преподавании русского языка как иностранного // МАПРЯЛ 2010. Десятый Международный симпозиум. Доклады и сообщения. Отв. ред. Гочев Г. - ВеликоТырново, 2010. - С. 5-11.

Димитрова С. Лингвистическая прагматика - генератор новых подходов к изучению языка и познания // МАПРЯЛ 2014. Одиннадцатый Международный симпозиум. Доклады и сообщения. Отв. ред. Гочев Г. - Велико-Тырново, 2014. - С. 13-18. 
Станкович Боголюб. Актуальные вопросы изучения и преподавания русского языка как инославянского // МАПРЯЛ 2010. Десятый Международный симпозиум. Доклады и сообщения. Отв. ред. Гочев Г. - Велико-Тырново, 2010. - С. 11-14.

Шеина И.М. Единицы и способы языковой концептуализации в деловом письме. Монография. Рязань: РГУ. 2012. - 340 с.

Dimitrina Spasova Lesnevskaya

\section{TRADITIONS AND CURRENT STATE OF THE BUSINESS STUDIES OF THE RUSSIAN LANGUAGE IN THE BULGARIAN RUSSIAN STUDIES}

\section{Summary}

The article traces the development of the theory and methodology of business studies of the Russian language in the works of Bulgarian researchers of the Russian language in chronological order. The analysis focuses on the functional stylistic, discursive-stylistic, discursive, pragmalinguistic and cognitive-pragmatic aspects of business Russian language, and it is determined that in most of the studies a comparative method of the study of two related Slavic business languages - Russian and Bulgarian has been used. Attention is drawn to the important role of the international conferences and symposiums, scientific journals and collections, contacts with experts of Russian language from different countries in the formation and development of the theory of business language studies in Bulgaria.

Key words: paradigm, business language, official business style, business discourse, intercultural business discourse, epistolary discourse, business letters, commercial letters, cognitive-pragmatic approach 